AGRICULTURE AND BIOLOGY JOURNAL OF NORTH AMERICA

ISSN Print: 2151-7517, ISSN Online: 2151-7525, doi:10.5251/abjna.2012.3.11.461.465

(C) 2012, ScienceHu $\beta$, http://www.scihub.org/ABJNA

\title{
Trans fatty acids effect on some serum enzymes and immunological parameters in Wistar albino rats
}

\author{
G.E Egbung; I.J Atangwho; E.H Itam and E.U Essien \\ Department of Biochemistry, College of Medical Sciences, University of Calabar, P.M.B 1115, \\ Calabar, Nigeria. \\ Correspondence :eneji6@yahoo.com
}

\begin{abstract}
The effect of trans fatty acids on some serum enzymes and immunological parameters in male albino Wistar rats was evaluated in this study. Fifty (50) male Wistar albino rats weighing between $100-140 \mathrm{~g}$ were divided into five groups of ten rats each. The animals were fed varying proportions of trans fatty acids (15\% and $25 \%$ ) respectively using margarine and thermoxidised palm oil as sources. The control received palletized grower's feed. The feeding experiment lasted for eight (8) weeks after which the animals were sacrificed and sera collected for analyses. Results showed significant decrease/increase in levels of alanine aminotransferase (ALT) and aspartate aminotransferase (AST) respectively.CD4+ levels and basophils count were increased in the test groups except group 3 compared to the controls. Lymphocytes showed significant decreases $(\mathrm{P}<0.05)$ in all the test groups except group 3 when compared to the control. Our findings did not reveal probable hepatotoxic effect and decreased immunity on consumption of of trans fatty acids.
\end{abstract}

Keywords: Immunological parameters, serum enzymes, Wistar rats and trans fatty acids

\section{INTRODUCTION}

Trans fatty acids are present in certain foods, arising as a by-product of the saturation of fatty acids during chemical hydrogenation, a process of adding hydrogen atoms in the presence of a metal catalyst (e. $g$ nickel) to unsaturated sites on the carbon chains of fatty acids especially during the margarine production. Partial hydrogenation accompanied by the thermal isomerisation represents incomplete saturation of the double bonds, in which some double bonds remain but may be shifted on the carbon chain and produce several geometrical and positional isomers. Partial hydrogenation became more popular in the 1930s with the advent of margarines. Also geometric isomers may come from the ingestion of ruminant fat that contains trans fatty acids arising from the action of microorganisms in the rumen (biohydrogenation). In consequence, milk fat, dairy products and beef and mutton fat also contain cis and trans fatty acids, although the proportions are somewhat different. In ruminants, the main component of the trans fatty acid is trans vaccenic acid (Masanori, 2002).
The major sources of trans fatty acids are baked foods (doughnuts, Danish pastry, imitation cheese, margarines confectionary fats, deep fried chicken, french fried potatoes and snack chips) when high trans oils are used in the frying process (Larque et al.,2001).

As palatable as these foods may be to consumers when moderation is not applied in their consumption, there could be some adverse biochemical or immunological effects. Food and Drug Administration (FDA) reported increased risk of coronary heart disease on consumption of high trans fats (Federal register, 1999). Dietary trans fatty acids have been implicated in the immune system, the splenic production of prostaglandins $E_{2}$ was reduced while both plasma lgG and CD4+ : CD8+ T-lymphocytes ratios were increased(Koga et al.,1997).

In the developing countries where there is abject poverty and especially in Nigeria, trans fatty acids is usually consumed in form of frying or bleached oils which are heated repeatedly during the processing of akara (made from beans paste), frying of fish, yam and plantain chips. Moreso, middle income earners consume trans fatty acids mostly as hydrogenated 
margarines. The above mentioned modes of consumption of trans fatty acids have caused considerable concern without substantial literature information to support how trans fatty acids affects other salient biochemical (enzymes) and immunological parameters. It is on this basis that this present study evaluated trans fatty acids effect on some serum enzymes and immunological parameters in Wistar albino rats.

\section{MATERIALS AND METHODS}

Preparation and formulation of diet: Fresh palm oil and margarine (ROSA) were purchased from Akim Qua market in Calabar Municipality, Cross River State, Nigeria. The pelletized commercial rat chow was purchased from Pfizer livestock Feeds, Aba, Abia State, Nigeria. The palm oil was used in preparing the thermally oxidized palm oil according to the methods of Isong et al., (1992). The thermally oxidized palm oil was prepared by heating one litre of fresh palm oil in a steel pot for 25 minutes at temperature of $160^{\circ} \mathrm{C}$ and allowed to cool for $2 \mathrm{hrs}$. This process was repeated for five (5) times and at the end, a thermally oxidized palm oil was obtained. The freshly prepared thermally oxidized palm oil and margarine (ROSA) served as sources of trans fatty acids. Each rat was expected to consume $12 \mathrm{~g}$ of feed daily hence the stock diet was prepared using the formula: $12 \mathrm{~g}$ of rat pellet $\times 10$ rats $\times 7$ days $=840$ $\mathrm{g}$. The detail formulation is shown in Table 1.

Table 1: Formulation of diet

\begin{tabular}{|l|c|l|c|}
\hline \multicolumn{1}{|c|}{ Group } & Number of rats & \multicolumn{1}{|c|}{ \% Feed composition ratio } & $\begin{array}{c}\text { Weight of feed } \\
\text { and oil (g) }\end{array}$ \\
\hline 1 (Control) & 10 & Rat pellet only & 840 \\
\hline 2 (Low margarine) & 10 & $\begin{array}{l}\text { Rat pellet (85\%) } \\
\text { Margarine (15\%) }\end{array}$ & $\begin{array}{c}768 \\
72\end{array}$ \\
\hline 3 (High margarine) & 10 & $\begin{array}{l}\text { Rat pellet (75\%) } \\
\text { Margarine (25\%) }\end{array}$ & $\begin{array}{c}678 \\
162\end{array}$ \\
\hline $\begin{array}{l}4 \text { (Low thermally } \\
\text { oxidized palm oil) }\end{array}$ & 10 & $\begin{array}{l}\text { Rat pellet (85\%) } \\
\text { Thermally oxidized palm oil (15\%) }\end{array}$ & 768 \\
\hline $\begin{array}{l}\text { (High thermally oxidized } \\
\text { palm oil }\end{array}$ & 10 & $\begin{array}{l}\text { Rat pellet (75\%) } \\
\text { Thermally oxidized palm oil (25\%) }\end{array}$ & 678 \\
\hline
\end{tabular}

Animals: A total of fifty healthy male albino Wistar rats weighing between 100 to $140 \mathrm{~g}$ were obtained from the disease free stock of the animal house, Department of Zoology, University of Calabar, Calabar. The animals were acclimitized for two weeks on pelletized rat chow and water provided ad libitum and were maintained under standard housing condition of adequate ventilation with room temperature $\left(28^{0} \mathrm{C} \pm 2^{0} \mathrm{C}\right)$ and relative humidity $(46 \%$ $\pm 5 \%$ ) and a natural 12 hour light -dark regimen in Biochemistry departmental animal house, where they were housed throughout the experiment. Permission and approval for the animal studies was obtained from the College of Medical Sciences animal ethics committee of the University of Calabar, Calabar, Nigeria.

Experimental design: The animals were housed in specially designed polycarbonated cages. The animals were weighed and assigned on the basis of weight and litter origin into five study groups of ten rats each. The first group being the control was fed with normal stock diet (pelletized rat diet).The second group was fed with $15 \%$ trans fatty acid (low concentration of margarine) supplemented with $85 \%$ rat pellet. The third group was fed with $75 \%$ rat pellet supplemented with 25\% trans fatty acid (High concentration of margarine). The fourth group was fed with $85 \%$ rat pellet supplemented with $15 \%$ trans fatty acid (low concentration of thermally oxidized palm oil).The fifth group was fed with $75 \%$ rat pellet supplemented with $25 \%$ trans fatty acid (high concentration of thermally oxidized palm oil).

On the last day of the feeding experiment, feed was withdrawn from the rats twelve hours to the time of sacrifice but they had free access to water ad libitum. The rats were euthanized with chloroform vapour and dissected for collection of blood samples for subsequent analyses.

Preparation of plasma and serum for biochemical assays: Whole blood obtained by cardiac puncture from each animal was collected into two sterile screw cap tubes $A$ and $B$. Tube $A$ was heparinized to collect plasma with its suspended blood cells intact, this was later used for immunological studies. Tube B was without anticoagulant and the whole blood collected was allowed to stand for $4 \mathrm{hrs}$ to clot and the serum was neatly separated from the clot by 
gentle tap with syringe and needle down the side of the sterile screw cap tubes. The tubes were further subjected to centrifugation using an MSE table top centrifuge (Minor, England) set at 8000 revolutions per minute (rpm) for 15 minutes, and a clear serum devoid of any trace of haemoglobin obtained. The sera samples were stored in a refrigerator at $4^{0} \mathrm{C}$ for subsequent enzyme analyses.

Enzyme assays: All chemicals and reagents used were of analytical grade.

Serum aspartate aminotransferase (AST) and alanine aminotransferase (ALT) were estimated by methods of Reitman and Frankel (1957) as employed in randox diagnostic kits while serum protein was determined by Biuret method (Dialab kit based on Thomas,1998, Tietz ,1976)
Immunological assays: Estimation of $\mathrm{CD}^{+}$, basophils and lymphocytes were carried out by use of cycloflow counter automated as employed by GHAIN 2000

Statistical analysis: Results were analysed by one way ANOVA using the SPSS statistical program and Post Hoc Test (LSD) between groups, using MS excel program. All data are expressed as Mean \pm SEM. $\mathrm{P}<0.05$ are considered significant.

\section{RESULTS:}

The results of effect of trans fatty acids effects on serum protein, serum alanine and aspartate aminotransferases activities as well as their computed AST/ALT ratio in Wistar albino rats are presented in table 2 while results of trans fatty acids effect on some immunological parameters in Wistar rats are presented in table 3

Table 2: Serum protein, aspartate aminotransferase, alanine aminotran sferase and their ratio in Wistar albino rats fed trans fatty acid.

\begin{tabular}{|l|l|c|c|c|}
\hline Group & Protein $(\mathrm{g} / \mathrm{dl})$ & AST $(\mathrm{U} / \mathrm{l})$ & ALT $(\mathrm{U} / \mathrm{l})$ & AST: ALT \\
\hline $1(\mathrm{LM})$ & $7.10 \pm 0.38^{\mathrm{a}}$ & $84.66 \pm 1.33^{\mathrm{a}}$ & $22.80 \pm 1.99^{\mathrm{a}}$ & 3.70 \\
\hline $2(\mathrm{HM})$ & $6.61 \pm 0.14^{\mathrm{a}}$ & $68.33 \pm 2.64^{\mathrm{b}}$ & $40.20 \pm 2.19^{\mathrm{e}}$ & 1.69 \\
\hline $3($ LTO) & $7.00 \pm 0.11^{\mathrm{a}}$ & $66.33 \pm 1.67^{\mathrm{b}}$ & $51.50 \pm 1.89^{\mathrm{b}}$ & 1.28 \\
\hline $4(\mathrm{HTO})$ & $6.58 \pm 0.11^{\mathrm{a}}$ & $69.25 \pm 1.25^{\mathrm{b}}$ & $26.50 \pm 1.42^{\mathrm{c}}$ & 1.26 \\
\hline $5(\mathrm{CTR})$ & $7.18 \pm 0.48^{\mathrm{a}}$ & $80.33 \pm 1.33^{\mathrm{a}}$ & $37.50 \pm 1.83^{\mathrm{a}}$ & 2.14 \\
\hline
\end{tabular}

Values are expressed as mean $\pm S D$, means with the same superscript along the same column are not significantly different at $\mathrm{P}>0.05$. $\mathrm{LM}=$ low margarine group, $\mathrm{HM}=$ high margarine group, $\mathrm{LTO}=$ low thermoxidised palm oil group, HTO= high thermoxidised palm oil group, CTR = control group

Table 3: Trans fatty acids effect on some immunological parameters in Wistar albino rats

\begin{tabular}{|c|l|c|c|c|c|c|}
\hline Group & CD4+ cell/ $\mu \mathrm{l}$ & $\begin{array}{c}\text { Basophil } \\
\%\end{array}$ & $\begin{array}{c}\text { Eosinophil } \\
\%\end{array}$ & $\begin{array}{c}\text { Monocyte } \\
\%\end{array}$ & $\begin{array}{c}\text { Lymphocyte } \\
\%\end{array}$ & $\begin{array}{c}\text { Neutrophil } \\
\%\end{array}$ \\
\hline $1(\mathrm{LM})$ & $12.40 \pm 2.07^{\mathrm{a}}$ & $3.60 \pm 1.14^{\mathrm{a}}$ & $7.60 \pm 0.54^{\mathrm{b}}$ & $6.80 \pm 0.83^{\mathrm{a}}$ & $61.00 \pm 1.00^{\mathrm{a}}$ & $21.00 \pm 1.58^{\mathrm{a}}$ \\
\hline $2(\mathrm{HM})$ & $9.60 \pm 1.81^{\mathrm{b}}$ & $3.60 \pm 0.54^{\mathrm{a}}$ & $4.80 \pm 1.09^{\mathrm{a}}$ & $5.80 \pm 0.83^{\mathrm{a}}$ & $61.20 \pm 1.30^{\mathrm{a}}$ & $24.60 \pm 1.14^{\mathrm{c}}$ \\
\hline $3(\mathrm{LTO})$ & $8.60 \pm 1.14^{\mathrm{b}}$ & $1.60 \pm 0.54^{\mathrm{b}}$ & $4.00 \pm 0.70^{\mathrm{a}}$ & $2.40 \pm 1.14^{\mathrm{b}}$ & $78.40 \pm 1.14^{\mathrm{b}}$ & $13.60 \pm 1.14^{\mathrm{b}}$ \\
\hline $4(\mathrm{HTO})$ & $10.00 \pm 1.58^{\mathrm{b}}$ & $3.20 \pm 0.44^{\mathrm{a}}$ & $7.00 \pm 0.70^{\mathrm{b}}$ & $5.80 \pm 0.83^{\mathrm{a}}$ & $63.60 \pm 1.14^{\mathrm{a}}$ & $20.40 \pm 0.54^{\mathrm{a}}$ \\
\hline $5(\mathrm{CTR})$ & $9.60 \pm 2.30^{\mathrm{b}}$ & $2.92 \pm 1.03^{\mathrm{a}}$ & $5.36 \pm 1.82^{\mathrm{a}}$ & $3.60 \pm 0.54^{\mathrm{b}}$ & $69.40 \pm 0.89^{\mathrm{c}}$ & $21.00 \pm 0.70^{\mathrm{a}}$ \\
\hline
\end{tabular}

Values are expressed as mean $\pm \mathrm{SD}$, means with the same superscript along the same column are not significantly different at $\mathrm{P}>0.05$. LM=Low margarine group, $\mathrm{HM}=$ High margarine group, LTO $=$ Low thermoxidised palm oil group, HTO $=\mathrm{High}$ thermoxidised palm oil group, CTR = Control group 


\section{DISCUSSION}

The serum protein concentrations in all the test groups viz; 1(low margarine),2 (high margarine), 3( low thermoxidised palm oil) and 4(high thermoxidised palm oil) were slightly decreased but these decreases were not significant $(P>0.05)$ when compared to group 5(control).Differences amongst group were not significant as well. The result obtained agrees with the findings of Narayan and Kummerow (1963) that reported proteins forming complexes with thermoxidised oils especially oleic and linoleic acids. This may have caused the non significant increase in serum proteins. There were significant decreases $(P<0.05)$ in activities of aspartate aminotransferase (AST) in groups (2, 3 and 4) fed high margarine, low thermoxidised palm oil and high thermoxidised palm oil respectively compared to group 5 fed normal rat chow, despite these decreases, there was an exception in group 1 that indicated a slightly higher value of AST activity compared to the control. The findings did not agree with the report of Lippel, (1975) who reported that dietary intake of trans fatty acids adversely affect enzyme activities. The probable reason could be that the quantity of trans fatty acids consumed by the animals did not cause any alterations in the activities of aspartate aminotransferase in all the test goups significantly. There were significant increases $(P<0.05)$ in activities of alanine aminotransferase in groups (2 and 3 ) fed high margarine) and low thermoxidised palm oil respectively, however, groups (1 and 4 ) fed $15 \%$ trans fatty acids in margarine form and $25 \%$ trans fatty acids in thermoxidised palm oil form respectively, indicated significant decreases relative to group 5( control). The possible explanation for the significant increase in activity of ALT in the two test groups (high margarine and low thermoxidised palm oil) as well as the significant increase in activity of AST in group 1 may be anchored on the tissue specificity of these two enzymes. According to report of Witschi (1980), toxicants interact with biochemical machinery of living cells causing subtle changes to vital tissue constituents including the enzyme activities in tissues and the extracellular fluid (ECF).Based on this, measurements of enzyme levels in blood have since been employed as a diagnostic tool and the assessment of functional status or lesions in cells and are carried out by monitoring the levels of specific enzymes in serum or urine. Transaminase activity has been reported to increase in liver disease, myocardial infarction and occasionally in renal infarction (Elemo, 1991). The AST/ALT value was greater than unity that tends to tilt the impact of trans fatty acids consumption towards the heart (Kumar et al.,2004), which agrees with the report of Willet et al.,(1993 ) that trans fatty acids has adverse effects on serum lipid levels and subsequently leads to coronary heart disease.

The serum CD4+ cell count in group 1 (low margarine) was significantly increased at $(P<0.05)$ when compared to group 5 (control). The CD4+ cell count is a measure of the immune status of an animal. The increased value may be an indication that the rats in this group were able to handle the amount of trans fatty acids consumed, however, the finding is completely in agreement with the report of Koga et al., (1997) where dietary intake of trans fatty acids increased plasma CD4+. The basophils count showed slight increases that were not statistically significant at $P>0.05$ in test groups $(1,2$ and 4$)$ when compared to group 5 ( control),however group 3 indicated non significant decrease . Basophilia is a condition where there is increase in blood basophils above $0.1 \times 10^{9} /$. The eosinophils level were significantly increased at $(\mathrm{P}<0.05)$ in test groups $(1$, and 4 ) but groups (2 and 3 ) indicated non significant decrease relative to group 5 (control). Eosinophilia is associated with parasitic disease example hookworm, filariasis, schistosomiasis and trichinosis as well as during recovery from acute infections. The monocytes were significantly increased at $(P<0.05)$ in group 2 (high margarine), group 4 (high thermoxidised palm oil) and group 1 (low margarine) when compared to group 5(control) but group 3 expressed non significant decrease relative to control. Monocytosis is associated with chronic bacterial infections, tuberculosis and typhoid (Hoffbrand et al., 2004). The lymphocytes count were significantly depressed $(P<0.05)$ in groups $(1,2$ and 4) but the low thermoxidised palm oil group expressed significant increase compared to group 5 . Lymphopenia is associated with HIV infection (Hoffbrand et al., 2004). The neutrophils in group 1 exhibited the same value with the control but comparison of group 2 relative to the control showed an increase relative to the control. A significant decrease was observed in group 3 (low thermoxidised palm oil) when compared to group 5 . The leucocytes particularly the polymorphonuclear capable of amoeboid movement that is polycytosis (ingestion of bacteria and other particulate matter).They therefore,act as body defense. Neutrophils are increased in acute bacterial infection and they are the main constituents of pus. Neutropenia is associated with viral infections, HIV, 
hepatitis, intoxications, poisoning by chemicals or drugs and influenza (Dacie and Lewis, 1991). However, an increase in neutrophil count does not always indicate infection (Baker and Silverton, 1985).

Conclusively, our findings did not reveal probable hepatotoxic effect and decreased immunity in Wistar albino rats following consumption of trans fatty acids.

\section{REFERENCES}

Baker, F.J \& Silverton, R.E (1985). Introduction to medical laboratory technology $6^{\text {th }}$ edition. London. Buttherworths

Dacie, J.V \& Lewis, S.M (1991). Practical haematology. $7^{\text {th }}$ edition, Edinburgh: Churchill Livingstone.

Elemo, B. O (1991).Biochemical studies on prolonged consumption of bouillon cubes: some pathophysiological effects in rats. Bioscience research communications 3 (2):131-140.

Hoffbrand, J. E; Petit, J.E \& Moss, P.A (2004). Essential haematology. Italy, Blackwell Publishing Ltd

Isong, E. U., Ifon, E. T., Eka, O. U., Essien, E. U. \& Umoh, I. B. (1992). Effects of intermittently thermoxidised palm oil on normal and malnourished rats. Tropical journal of applied science 2: 118-121.

Koga, T; Nonaka, M; Gu, J.Y \& Sugano, M (1997) Linoleic and alpha -linoleic acids differently modify the effects of elaidic acid on polyunsaturated fatty acid metabolism and some immune indices in rats. British journal of nutrition 77:645-656

Kumar,V,Abbas,K \& Fausto,N (2004). Robbins and cotran pathologic basis of disease. India, Elsevier
Larque,E;Zamora,S \& Gil,A (2001).Dietary trans fatty acids in early life: a review. Early human development 65(supplement): s31-s41.

Lippel,K (1975) .Activation of long chain fatty acids by subcellular fractions of rat liver:activation of trans unsaturated acids. Lipids 8:111-18

Masanori, S (2002).Trans fatty acids: Properties, benefits and risks. Journal of health science, 48(1) 7-13

Narayan, K. A \& Kummerow, F.A (1963). Factors influencing the formation of complexes between oxidized lipids and proteins. Journal of American oil chemical society 40:339-342

Reitman,S \& Frankel,S (1957) Detemination of aspartate and alanine aminotransferase activity in blood serum and tissues. .American journal of clinical pathology,28: 56.

Thomas, L (1998). Clinical laboratory diagnostics. $1^{\text {st }}$ edition, Frankfurt: Vertagsgesilschaft Books

Tietz, N.W (1976). Fundamentals of clinical chemistry. Philadelphia: W.B Saunders.

Willet,W.C.,Stampfer,M.J.,Manson,J.E.,Colditz,G.A.,Speize r,F.E.,Rosner,B.A.,Sampson,L.A \& Hennekens,C.H (1993).Intake of trans fatty acids and the risks of coronary heart disease among women .Lancet 341:581-585

Witschi, H.R (1980). Mechanism in organ and tissue damage. Introduction in Hanspeter, R. Witschi (ed). Scientific basis of toxicity assessment -Syposium on scientific basis of toxicity assessment. Development in toxicology and environmental sciences 6:165-166. 